\title{
Consumer Problems Faced by Residents of SDAU Campus, Dantiwada, India
}

\author{
Aayushi Saini*, Singh Surabhi Singh and Kirtiraj Dabhi
}

Family Resource Management, Sardarkrushinagar Dantiwada Agricultural University, Sardarkrushinagar, Gujarat, India

*Corresponding author

\begin{abstract}
A B S T R A C T
Consumers are the largest economic group in any country. They are the central point of all economic activities of the nation. Despite of various laws and acts to protect consumers, businessmen make fraudulent pand malpractices and exploit consumers. Consumer education is the only way to make consumers aware about selection of products and services. Consumers face various types of problems related to products and services. Hence there is a need to find out the solutions and create awareness to reduce the consumer problems. Hence, a study was conducted to find out the consumer problems between two areas D+E quarters and F-quarters at SDAU campus, Dantiwada of Gujarat state. It is noted here that F- quarters are for Class IV employees and D+E quarters are for Class II employees. The data were collected through interview schedule on a sample of 60 respondents (30 sample from D+E quarter and 30- sample from F- quarter) through random sampling. Descriptive and relational statistics was used for presenting results. The findings of the study regarding educational level revealed that forty per cent respondents in D+E Quarter were graduates and Post Graduates while in F- Quarters almost one-fourth respondents were Illiterate. Members of the family was classified into three categories and it was found that majority of family members in D+E and FQuarters lived in small Family (60\% -70\%) and none of the members lived in the large family. Problems faced by the consumers of D+E quarters were substandard quality of product, deceptive packaging and adulterated food. Problems faced by consumers in F quarters were reported as problems in telecommunication, deceptive packaging, substandard quality, high prices, deceptive goods and getting less amount of material.
\end{abstract}

\begin{tabular}{|l|}
\hline Key w o r d s \\
Consumer \\
Problems, \\
$\begin{array}{l}\text { Residents \& } \\
\text { Campus }\end{array}$ \\
\hline Article Info \\
\hline $\begin{array}{l}\text { Accepted: } \\
\text { 17 June 2020 } \\
\text { Available Online: } \\
\text { 10 July 2020 }\end{array}$ \\
\hline
\end{tabular}

\section{Introduction}

In India, the credit of starting the first consumer protection council goes to $\mathrm{C}$. Rajagopalachari which he formed for Madras in around 1950. Then the government took note of the developments and came forward with the Consumer Protection Council in 1983 and Consumer Protection act, in 1986. Later half of $20^{\text {th }}$ century is said to be the era of consumers. The basic objective of Consumer Protection Act, 1986 is to promote and protect consumer's rights (Anon, 1995).

The consumer is one who buys goods for consumption which has been paid or promised, partially paid or partially promised or under any system of deferred payment. The consumer means a person who hires any services for consideration, which has been 
paid or promised or partly paid or partly promised or under any system of deferred payment.

The retail shopkeepers buy product from wholesalers use this money to get supplies from producers and processors. The products related problems of consumer are with prices, quality and weights or volume of products available in the market. There are various types of problem faced by consumers just like lack of safety and quality control regulation, adulteration, imitation manufactures, incorrect weights and measures, deceptive goods, misleading advertisements, incomplete labels, deceptive packaging, prices, substandard quality, unfair warranties, sale gimmicks, dishonest vending, black marketing and hoarding.

According to the Ozimek and Banasiak (2000), salesman had the knowledge of consumer rights but only less than half of the respondent was able to name an organisation working on consumer protection. Minakshi (2002) highlighted that nearly 25.00 per cent of respondents knew about the term consumer, consumerism and consumer education. She further stated the percentage of respondents aware about consumer problems were as follows - adulteration (28.00\%), overpricing (13.00\%), black marketimg $(16.00 \%)$, duplicate products $(23.00 \%)$, faulty weights and measures (25.00\%), misleading advertisement $(23.00 \%)$, reduction sale $(14.00 \%)$ and free offer $(23.00 \%)$. This paper deals with the consumer problems faced by family members of SDAU employees. The objectives of the study are to find out different kinds of problem faced by the consumers residing in SDAU campus.

\section{Materials and Methods}

The research designs for the present investigation were descriptive. The sample was collected from SDAU from D+E Quarters and F- Quarters purposively. From each areas viz. D+E Quarter(Upper class) and F- Quarter(Lower class) , 30 respondents were selected through simple random sampling comprising a sample size of 60 respondents. A pre structured interview schedule was used for data collection. The collected data were analysed using descriptive statistics in terms of frequency and percentage. The responses were "Never Faced", "Sometimes Faced" and "Frequently Faced" where the scores ascribed were from 1 through 3 respectively to these responses.

\section{Results and Discussion}

The findings of the study obtained through the analysis of the data, supported discussion and interpretations are presented here.

\section{Background information of the respondents}

This section deals with the personal and family information of the respondent.

\section{Personal variables}

Majority of the respondents were female (70 $\%)$. As far as age of the respondents is concerned, slightly less than half of the respondents in $\mathrm{D}+\mathrm{E}$ Quarters belonged to age group of 53 years and above (46.66\%), although more than half of the respondents in F- quarters were between 18 to 35 years old. On analyzing the educational level of the respondents, it was observed that in $\mathrm{D}+\mathrm{E}$ Quarters 20 per cent respondents were Post Graduate while in F- Quarters, almost onefourth of the respondents were Illiterate (Table-3, Fig. 3).

\section{Family variables}

Members of the family were classified into three categories. It was found that majority of respondents in both the Quarters lived in small Family $(60 \%-70 \%)$ and also found that 
none of the members lived in the large family (Fig. 4). On analyzing the monthly family income, it was found that majority $(80 \%)$ of the respondents in $\mathrm{D}+\mathrm{E}$ belonged to High income group but monthly family income of majority of the respondents $(93.34 \%)$ in FQuarter was 25000 to 35000 (Table - 4, Fig. $5)$.

Table.1 Distribution of respondents according to their gender

\begin{tabular}{|l|l|c|c|c|c|}
\hline S. & Gender & \multicolumn{2}{|c|}{ D+E Quarter } & \multicolumn{2}{|c|}{ F- Quarter } \\
\cline { 3 - 6 } No. & & F & $\mathbf{( \% )}$ & F & $(\mathbf{\%})$ \\
\hline $\mathbf{1}$ & Male & 9 & 30 & 9 & 30 \\
\hline $\mathbf{2}$ & Female & 21 & 70 & 21 & 70 \\
\hline & Total & $\mathbf{3 0}$ & $\mathbf{1 0 0}$ & $\mathbf{3 0}$ & $\mathbf{1 0 0}$ \\
\hline
\end{tabular}

Table.2 Distribution of respondents according to their age

\begin{tabular}{|c|l|c|c|c|c|}
\hline S. & Age & \multicolumn{4}{|c|}{ Respondent n=60 } \\
\cline { 3 - 7 } & & \multicolumn{2}{|c|}{ D+E Quarter } & \multicolumn{2}{|c|}{ F- Quarter } \\
\hline i. & $\begin{array}{l}\text { 18-35 } \\
\text { Younger }\end{array}$ & 11 & 36.66 & 14 & 46.66 \\
\hline ii. & 36-52 Middle & 15 & 16.66 & 12 & 40 \\
\hline iii. & $\begin{array}{l}\text { 53 Above- } \\
\text { Old }\end{array}$ & 14 & 46.66 & 4 & 13.33 \\
\hline & Total & $\mathbf{3 0}$ & $\mathbf{1 0 0}$ & $\mathbf{3 0}$ & $\mathbf{1 0 0}$ \\
\hline
\end{tabular}

Table.3 Distribution of respondents according to their education

\begin{tabular}{|c|c|c|c|c|c|}
\hline \multirow[t]{3}{*}{ S. No. } & \multirow[t]{3}{*}{ Education } & \multicolumn{4}{|c|}{$\begin{array}{c}\text { Respondent } \\
\mathbf{n}=\mathbf{3 0}\end{array}$} \\
\hline & & \multicolumn{2}{|c|}{ D+E Quarter } & \multicolumn{2}{|c|}{ F- Quarter } \\
\hline & & $\mathbf{F}$ & $(\%)$ & $\mathbf{F}$ & $(\%)$ \\
\hline i. & Illiterate & 0 & 0 & 7 & 23.33 \\
\hline ii. & Primary NURSURY 5 & 1 & 3.33 & 3 & 10 \\
\hline iii. & Middle6-8 & 3 & 10 & 3 & 10 \\
\hline iv. & High school9-10 & 3 & 10 & 6 & 20 \\
\hline v. & Higher Secondary 11-12 & 4 & 13.33 & 3 & 10 \\
\hline vi. & Diploma/PTC & 7 & 23.33 & 0 & 0 \\
\hline vii. & Graduate & 6 & 20 & 7 & 23.33 \\
\hline viii. & $\begin{array}{l}\text { Post-Graduate and } \\
\text { above }\end{array}$ & 6 & 20 & 1 & 3.33 \\
\hline & Total & 30 & 100 & 30 & 100 \\
\hline
\end{tabular}


Table.4 Distribution of respondents according to their family income

\begin{tabular}{|r|c|c|c|c|c|}
\hline \multirow{2}{*}{$\begin{array}{l}\text { S. } \\
\text { No. }\end{array}$} & \multicolumn{4}{|c|}{$\begin{array}{c}\text { Respondent } \\
\text { n=60 }\end{array}$} \\
\cline { 3 - 6 } & & \multicolumn{3}{|c|}{ D+E Quarter } & \multicolumn{2}{c|}{ F- Quarter } \\
\cline { 3 - 6 } & & F & $\mathbf{( \% )}$ & 28 & $(\%)$ \\
\hline i. & Low(Rs.25,000 to 35,000) & 00 & 00 & 02 & 63.34 \\
\hline ii. & Medium(Rs.35,001 to 50,000) & 06 & 20 & 00 & 00 \\
\hline iii. & High(Rs.50,001 to above) & 24 & 80 & 30 & 100 \\
\hline & Total & 30 & 100 & & \\
\hline
\end{tabular}

Table.5 Consumer Problem faced by the Respondents in D+E Quarters

\begin{tabular}{|c|c|c|c|c|c|c|c|}
\hline \multicolumn{8}{|c|}{ D+E Quarter } \\
\hline \multirow[t]{3}{*}{ S. No. } & \multirow[t]{3}{*}{ Consumer problem } & \multicolumn{6}{|c|}{ Respondent $(\mathrm{n}=\mathbf{3 0})$} \\
\hline & & \multicolumn{2}{|c|}{ Never Faced } & \multicolumn{2}{|c|}{$\begin{array}{l}\text { Sometimes } \\
\text { Faced }\end{array}$} & \multicolumn{2}{|c|}{$\begin{array}{l}\text { Frequently } \\
\text { Faced }\end{array}$} \\
\hline & & (F) & $(\%)$ & (F) & $(\%)$ & (F) & $(\%)$ \\
\hline 1. & Do you get adulterated food? & 14 & 46.67 & 14 & 46.67 & 2 & 6.67 \\
\hline 2. & Do you get less amount of material? & 13 & 43.33 & 14 & 46.67 & 3 & 10 \\
\hline 3. & $\begin{array}{l}\text { Do you face the problem of lack of safety and } \\
\text { quality control regulation? }\end{array}$ & 26 & 86.67 & 4 & 13.33 & 0 & 0 \\
\hline 4. & $\begin{array}{l}\text { Do you face the problem of dishonest } \\
\text { vending? }\end{array}$ & 21 & 70 & 9 & 30 & 0 & 0 \\
\hline 5. & $\begin{array}{l}\text { Do you face the problem of Imitation } \\
\text { manufacture? }\end{array}$ & 23 & 76.67 & 6 & 20 & 1 & 3.33 \\
\hline 6. & Do you get deceptive goods? & 12 & 40 & 15 & 50 & 3 & 10 \\
\hline 7. & $\begin{array}{l}\text { Are the advertisements misleading related to } \\
\text { various products? }\end{array}$ & 23 & 76.67 & 5 & 16.67 & 2 & 6.67 \\
\hline 8. & $\begin{array}{l}\text { Do you think labels have incomplete } \\
\text { information? }\end{array}$ & 22 & 73.33 & 8 & 26.67 & 0 & 0 \\
\hline 9. & $\begin{array}{l}\text { Do the products are in packed in deceptive } \\
\text { packaging? }\end{array}$ & 17 & 56.67 & 13 & 43.33 & 0 & 0 \\
\hline 10. & Do you face the problem of high prices? & 16 & 53.33 & 13 & 43.33 & 1 & 3.33 \\
\hline 11. & $\begin{array}{l}\text { Do you face the problem of substandard } \\
\text { quality? }\end{array}$ & 12 & 40 & 16 & 53.33 & 2 & 6.67 \\
\hline 12. & $\begin{array}{l}\text { Are you face the problem for warranties and } \\
\text { guaranties? }\end{array}$ & 26 & 86.67 & 4 & 13.33 & 0 & 0 \\
\hline 13. & Do you know? What are the sale gimmicks? & 29 & 96.67 & 1 & 3.33 & 0 & 0 \\
\hline 14. & Do you face the problem of black marketing? & 30 & 100 & 0 & 0 & 0 & 0 \\
\hline 15. & $\begin{array}{l}\text { Do you get face service problem? Just } \\
\text { like,cooking gas, water electricity, medical } \\
\text { and hospital service, educational service }\end{array}$ & 26 & 86.67 & 3 & 10 & 1 & 3.33 \\
\hline 16. & Do you face the problem of deceptive service? & 18 & 60 & 12 & 40 & 0 & 0 \\
\hline 17. & $\begin{array}{l}\text { Do you face the problem of } \\
\text { telecommunication? }\end{array}$ & 15 & 50 & 15 & 50 & 0 & 0 \\
\hline
\end{tabular}


Table.6 Consumer problem faced by the respondents in F- quarters

\begin{tabular}{|c|c|c|c|c|c|c|c|}
\hline \multicolumn{8}{|c|}{ F- Quarter } \\
\hline \multirow[t]{3}{*}{ S. No. } & \multirow[t]{3}{*}{ Consumer problem } & \multicolumn{6}{|c|}{$\begin{array}{c}\text { Respondent } \\
n=30\end{array}$} \\
\hline & & \multicolumn{2}{|c|}{ Never Faced } & \multicolumn{2}{|c|}{$\begin{array}{l}\text { Sometimes } \\
\text { Faced }\end{array}$} & \multicolumn{2}{|c|}{$\begin{array}{l}\text { Frequently } \\
\text { Faced }\end{array}$} \\
\hline & & (F) & $(\%)$ & (F) & $(\%)$ & (F) & $(\%)$ \\
\hline 1. & Do you get adulterated food? & 20 & 66.67 & 8 & 26.67 & 2 & 6.67 \\
\hline 2. & Do you get less amount of material? & 16 & 53.33 & 14 & 46.67 & 0 & 0 \\
\hline 3. & $\begin{array}{l}\text { Do you face the problem of lack of } \\
\text { safety and quality control regulation? }\end{array}$ & 21 & 70 & 9 & 30 & 0 & 0 \\
\hline 4. & $\begin{array}{l}\text { Do you face the problem of dishonest } \\
\text { vending? }\end{array}$ & 19 & 63.33 & 11 & 36.67 & 0 & 0 \\
\hline 5. & $\begin{array}{l}\text { Do you face the problem of Imitation } \\
\text { manufacture? }\end{array}$ & 20 & 66.67 & 10 & 33.33 & 0 & 0 \\
\hline 6. & Do you get deceptive goods? & 15 & 50 & 14 & 46.67 & 1 & 3.33 \\
\hline 7. & $\begin{array}{l}\text { Are the advertisements misleading } \\
\text { related to various products? }\end{array}$ & 19 & 63.33 & 10 & 33.33 & 1 & 3.33 \\
\hline 8. & $\begin{array}{l}\text { Do you think labels have incomplete } \\
\text { information? }\end{array}$ & 20 & 66.67 & 10 & 33.33 & 0 & 0 \\
\hline 9. & $\begin{array}{l}\text { Do the products are in packed in } \\
\text { deceptive packaging? }\end{array}$ & 14 & 46.67 & 16 & 53.33 & 0 & 0 \\
\hline 10. & $\begin{array}{l}\text { Do you face the problem of high } \\
\text { prices? }\end{array}$ & 16 & 53.33 & 14 & 46.67 & 0 & 0 \\
\hline 11. & $\begin{array}{l}\text { Do you face the problem of } \\
\text { substandard quality? }\end{array}$ & 13 & 43.33 & 16 & 53.33 & 1 & 3.33 \\
\hline 12. & $\begin{array}{l}\text { Are you face the problem for } \\
\text { warranties and guaranties? }\end{array}$ & 26 & 86.67 & 4 & 13.33 & 0 & 0 \\
\hline 13. & $\begin{array}{l}\text { Do you know? What are the sale } \\
\text { gimmicks? }\end{array}$ & 21 & 70 & 9 & 30 & 0 & 0 \\
\hline 14. & $\begin{array}{l}\text { Do you face the problem of black } \\
\text { marketing? }\end{array}$ & 23 & 76.67 & 7 & 23.33 & 0 & 0 \\
\hline 15. & $\begin{array}{l}\text { Do you get face service problem? Just } \\
\text { like cooking gas, water electricity, } \\
\text { medical and hospital service, } \\
\text { educational service }\end{array}$ & 22 & 73.33 & 8 & 26.67 & 0 & 0 \\
\hline 16. & $\begin{array}{l}\text { Do you face the problem of deceptive } \\
\text { service? }\end{array}$ & 19 & 63.33 & 11 & 36.67 & 0 & 0 \\
\hline 17. & $\begin{array}{l}\text { Do you face the problem of } \\
\text { telecommunication? }\end{array}$ & 13 & 43.33 & 17 & 56.67 & 0 & 0 \\
\hline
\end{tabular}


Figure.1 Distribution of respondents according to their Gender

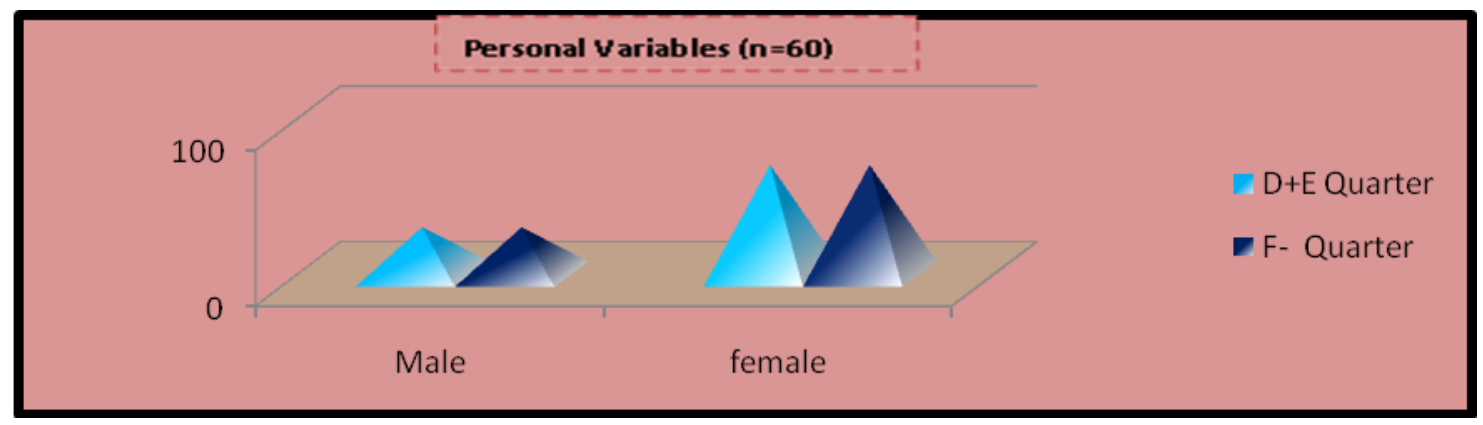

Fig.2 Distribution of Respondents According To Their Age

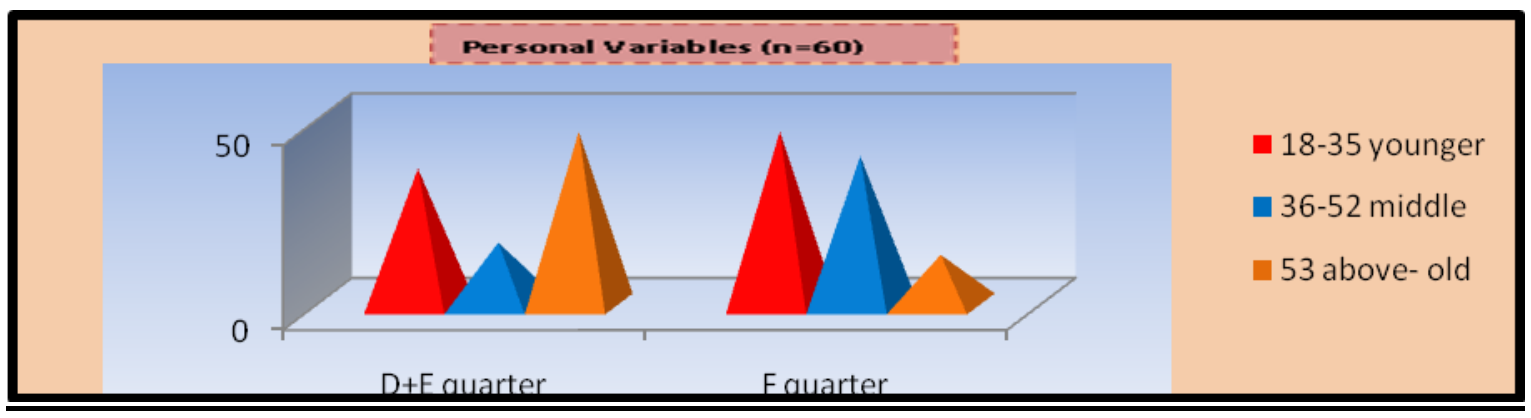

Fig.3 Distribution of respondents according to their education

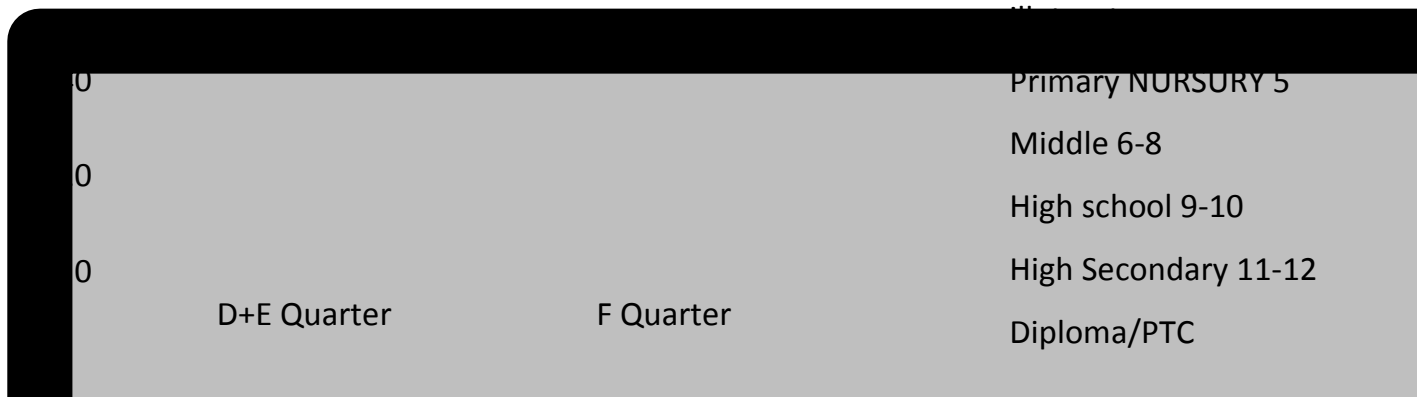

Fig.4 Distribution of respondents according to family members

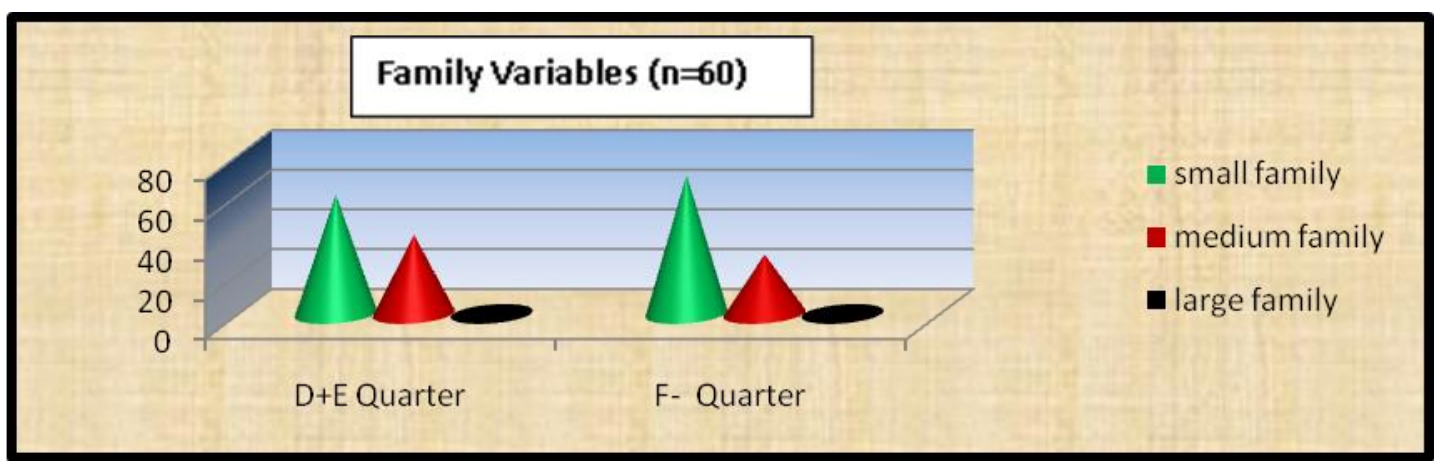


Fig.5 Distribution of respondents according to their family income

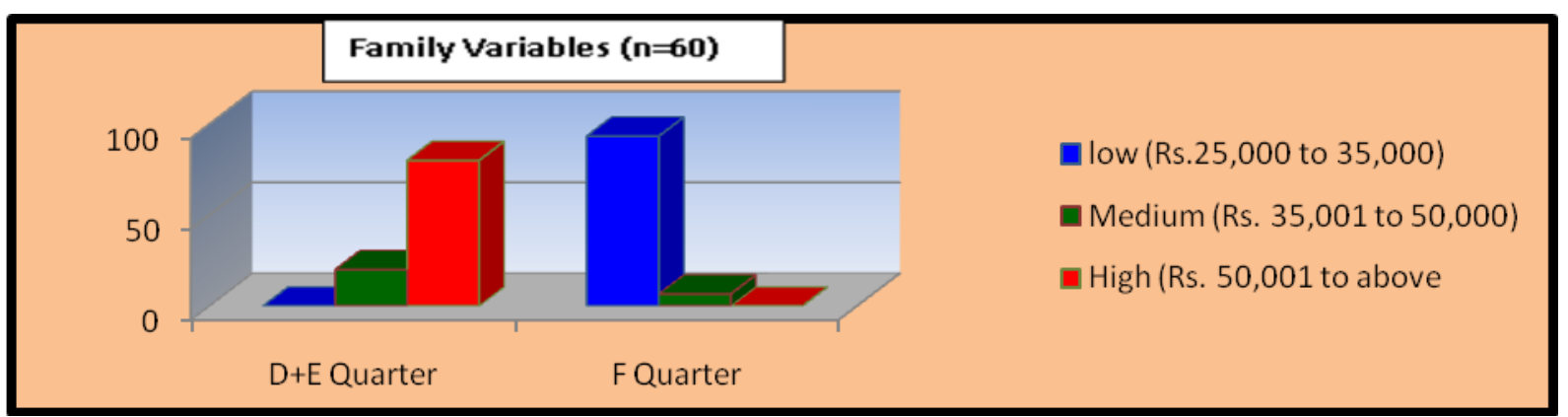

This section deals with consumer problems in $\mathrm{D}+\mathrm{E}$ Quarter. List of different kinds of problems faced by the respondents was made and they were requested to give their responses in Never Faced, Sometimes Faced and Frequently Faced pattern.

It was found that almost half $(53.33 \%)$ of the consumers sometimes faced the problem of substandard quality product. Little less than half of the consumers faced the problems of getting adulterated food $(46.67 \%)$ and less quantity of material (46.67 \%). Around forty three per cent consumers also faced the problem of deceptive packaging. Further, the data also highlighted that majority of the consumers never faced the problem regarding sale gimmicks $(96.67 \%)$, lack of safety and quality control regulation (86.67\%), warranties and guaranties of the product $(86.67 \%)$ and never faced the problem of incomplete information on the lable $(73.33 \%)$ (Table-6).

Further, the results revealed that in $\mathrm{F}$ quarters, more than half $(56.67 \%)$ of the consumers sometimes faced the problems in telecommunication and products packed in deceptive packaging (53.33\%). Little less than half of the consumers $(46.67 \%)$ sometimes faced problems of substandard quality of products, high prices, deceptive goods and less amount of material (Table-7). Interestingly it was found that majority of the consumers never faced the problem of lack of safety and quality control regulation, warranties and guaranties, sale gimmicks, black marketing and service problem.

It is concluded that in resident area $D+E$ quarters, majority of the residents faced the problem of substandard quality product and half of the respondents faced the problems of getting adulterated food and less quantity of material.

Further F-quater respondents pointed out the problems regarding telecommunication, products packed in deceptive packaging and half of the consumers faced problems of substandard quality of products, high prices, deceptive goods and less amount of materials.

It can be concluded from the research that consumers should be aware towards the products quality and other related issues. Collecting information before purchasing products is essential for consumers so that they can be prevented from exploitation.

\section{References}

Anonymous (1995). The Consumer Protection Act, 1986. University Book Traders, New Delhi. Pp. 1-8.

Ozimek, I. and Banasaik, M. (2000). "Evaluation of consumer rights knowledge shown by salesmen according to questionnaires study." Annals of Warsaw Agricultural 
University. 127-135

Minakshi (2002). Stadardization of Educational material on consumer education for senior secondary school children. M.Sc. Thesis, Submitted to Chaudhary Charan Singh Haryana Agricultural University, Hisar, India.

\section{How to cite this article:}

Aayushi Saini, Singh Surabhi Singh and Kirtiraj Dabhi. 2020. Consumer Problems Faced by Residents of Sdau Campus, Dantiwada Int.J.Curr.Microbiol.App.Sci. 9(07): 2080-2087.

doi: https://doi.org/10.20546/ijcmas.2020.907.241 